\title{
EFFECTIVENESS OF TRAINING FOR 11-13 YEAR-OLD SOCEER PLAYERS ON THE BASIS OF SMALL AND SUPPORTING GAMES IN THE CONTEXT OF ACTION EFFICIENCY IN THE SITUATION OF A ONE AGAINST ONE GAME
}

\author{
Andrzej Lachowicz \\ Akademia Morska w Gdyni, Poland \\ Address for correspondence: \\ Andrzej Lachowicz \\ Akademia Morska w Gdyni \\ Morska 81-87, 81-225-Gdynia, Poland \\ E-mail: a.lachowicz@swfis.am.gdynia.pl
}

\begin{abstract}
Ahstract A particular meaning in contemporary soccer games is gained by the efficiency of actions in the situation of a 1 on 1 game. The application of an increased number of exercises based on small and supporting games in soccer training can help to increase the effectiveness of training in this aspect. The aim of the work was to determine the effectiveness of training for 11-13 year-old soccer players with the use of small and supporting games to improve actions during a one against one game. The tests were applied to a group of 11-13 year-old soccer players. We have conducted a pedagogical experiment, the fundamental element of which was to apply training based on small and supporting games in the experimental group, and then tracing the changes on the background of the comparative group. In order to diagnose differences in the effects of training, we have applied a set of test tasks (cycle of $1 \times 1$ simulation games, test of general physical fitness INKF). The applied training improved the actions in $1 \times 1$ simulation games. Throughout the experiment, the players from both teams presented a comparable level of the tested motor skills. The training based on small and supporting games seems to be an effective method of increasing training effectiveness in the context of action improvement in the situation of a $1 \times 1$ game.
\end{abstract}

Key Worlls football, training, boys at 11-13 years of age, small and auxillary games, 1 v.1 plays

\section{Introduction}

The dominant trend in the organization of actions when playing soccer in the tactics of the best teams is the obligation to narrow and shorten the game field in a defensive game as well as to aggressively attack the opponent with the intention of provoking him to make a mistake and in consequence take the ball from him (Duda, 2004, 2006; Panfil, Żmuda, 1996; Stępiński, 2005, 2006; Stuła, 1998; Talaga, 2006; Wrzos, 1999, 2000, 2005; Zieliński, 1999).

The above-mentioned method of defensive game is applied by all the best teams in the world regardless of the assumed game system. As a consequence, a change of conditions occurs in which the players of the attacking team have to play. We observe a distinct increase in the number of actions in the situation of a $1 \times 1$ game and also 
its meaning for the final result of meeting. Szwarc and Kromke (2011) analyze the matches played during the final tournaments of world's and Europe's championships in the years 1994-2008 (semifinals and finals) and stated that soccer players with the highest sport competence use on average from 200 to 300 duels in $1 \times 1$ game situations during one match, with average $50 \%$ reliability.

Individual actions of a player in a 1 on 1 situation, both in attack and defense, should be recognized as essential for a modern soccer game (Bergier, 1998; Clemente, Couceiro, Martins, Dias, Mendes, 2013; Duda, 2006; Paluszek, Nosal, 1997; Paluszek, Panfil, 1995; Panfil, Żmuda, 1996; Stępiński, 2006; Stępiński, Dorna, 2011; Szwarc, 2004, 2005a, 2005b, 2005c, 2007; Talaga, 1997b; Witkowski, Ljach, 2004; Wrzos, 1998, 1999, 2000, 2005; Zieliński, 1999).

Szwarc (Szwarc, 2012, p. 32) defines a 1 on $1(1 \times 1)$ game as the "direct influence of two players of competitive teams, heading for the realization of contradictory aims in the form of rules determined by regulations. A $1 \times 1$ game in attacking is the entirety of reactions and actions of the player owning the ball oriented on one rival, going for scoring points (goals) or creating a situation in order to achieve it or the intention of capturing the field and/or holding the ball. The actions and behaviors of a player against the player with the ball striving to take it away, interrupting his actions or hindering the movement of the ball, is the game one against one in defense".

All the elements of game technique should be improved with a creative and reproductive method in conditions approaching the games with high involvement of trained players (Panfil, Żmuda, 1996). Hence, the application of a higher number of exercises based on small and supporting forms in soccer player training seems to be helpful in solving the problem of proper forms, methods and training resource choice, as to cope with the requirements of modern soccer. Such training creates open problems for the players, the solution of which needs technical skills, physical fitness, knowledge and tactic awareness as well as an adequate level of mental preparation, and all these in direct confrontation with a rival (Dorna, Robakiewicz, Dorożała, 2015).

Small-sided games constitute a tool for coaches to boost their trainees' motivation, and thus to improve exercise intensity and enhance the players' stamina (Mallo, Navarro, 2012; Hill-Haas, Coutts, Rowsell, Dawson, 2008; Hill-Hass, Dawson, Coutts, Rowsell, 2009; Hill-Haas, Coutts, Dawson, Rowse, 2010; Martone, Giacombbe, Capobianco, Imperlini, Mancini, Campasso, Buono, Orru, 2016). They may also serve as a talent identification tool with respect to young players (Fenner, Iga, Unnithan, 2016).

For the needs of the work, we accepted the definition of small games by Talaga (Talaga, 1997b), who claims that we can consider a game as small when the rules, and mainly the field dimension, goal dimension, size and weight of ball, game time, number of players is simplified, adapted to training needs and age of players, in each case the number of struggling players on each side is similar (equal chances); moreover, the number of players on both sides does not exceed 14 . Hence, the following forms can be treated as small games: $1 \times 1,2 \times 2,3 \times 3,4 \times 4$, $5 \times 5,6 \times 6,7 \times 7$ (Talaga, 2000, p. 19).

In turn, the number of supporting games (Przybylski, Szwarc, 1996, p. 63) can include "games with an uneven number of attacking and defending players (i.e. $2 \times 1,4 \times 2,3 \times 4)$ ".

\section{The objective and aim of research}

The objective of the research was the training process of 11-13 year-old soccer players with orientation on small and supporting games. 
The aim of the research was to determine the effectiveness of training for 11-13 year-old soccer players with the usage of small and supporting games to improve actions during a proper game.

\section{Research questions}

1. Will the soccer training based on small and supporting games applied in the experimental group prove the effect of increased efficiency of actions in relation to the comparative group in a simulation game of $1 \times 1$ ?

2. Which level of motor skills is representative for the tested players of both research groups?

3. How will the differentiation of training influence the changes in the level of motor skills in both research groups?

\section{Methods}

To solve the research problem, we conducted a pedagogical experiment. The tests were conducted on a group of 11-13 year-old boys, who specialize in playing soccer at Uczniowski Klub Sportowy Cisowa Gdynia.

Before we proceeded to the realization of the pedagogical experiment, we conducted a recruitment, selection, and a two-year soccer training based on the assumptions of the initial stage of preparation (Kapera, Śledziewski, 1997; Szyngiera, Bibrzycki, 1994). The recruitment was conducted among students of the third classes of primary schools in Gdynia. After 10 months of training, among 40 selected boys, we randomly chose 20 players for each of the training groups. The following year, both teams were still trained in identical conditions, with the same intensity and according to the same training plan.

After two years of initial training, we started the pedagogical experiment, the essential element of which was to introduce differences in training plans prepared for both groups. From that moment, the comparative group ( $n=18$ ) was training in a "traditional" way, with the use of variable forms and training methods, in proportion choice basing on available topic literature (Bauer, 2001; Behnke, Sass, 1990; Cicirko, Syryjczyk, 2000; Gołaszewski, 2003; Hamsun, Daniel, 2000; Harwey, Dungworth, 1999; Kapera, 1999; Kapera, Śledziewski, 1997; Kollatch, 1998; Mayer, 1996; Naglak, 1996, 2005; Paluszek, 2003; Panfil, Żmuda 1996; Patz, 2000; Przybylski, 1998; Przybylski, Szwarc, 1996; Stuła, 2001; Szyngiera, Bibrzycki, 1994; Talaga, 1997a). At the same time, the experimental group $(n=18)$ underwent soccer training, the basis of which were small and supporting games. The contents included in the training were chosen for the particular aims of training in the range of technique, tactics improvement and shaping particular motor skills realized basing on small and supporting games.

Training plans prepared for both groups were constructed in respect to the number of trainings, control meetings, championship meetings, days on camps and free days. The differences in training plans concerned a proportion of the applied training forms during the main parts of particular training units.

The time structure of the applied training forms towards the experimental group, during a two-year period of training, included: $70 \%$ of small and supporting games, $10 \%$ of teaching and improving technique elements in a proper form, other training forms (play, fragments of game, school game, stream, alternate, balance, parallel, station, peripheral, related - 20\%). In turn, during the discussion period, in the comparative group, we used training with the following time structure (in the main parts of all training units conducted in the testing period): proper form $-40 \%$, play form $-20 \%$, game form $-30 \%$, the other forms (game fragments, stream, alternate, balance, parallel, station, peripheral, related) $-20 \%$. 
Training in this form was finished after two macrocycles, which, for the tested group, coincided with the end of primary school.

It should be emphasized that everyone participated in the research at their own free will and did not report any complaints of physical disorders.

To diagnose the differences in the effects of training between the comparative and the experimental group, all the players were subjected to cyclic tests repeating above the presented set of test tasks every half a year.

The first set of test tasks was conducted at the starting point of the first training macrocycle (the beginning of the experiment); the last - at the end of the second macrocycle (the end of the experiment).

\section{The set of test tasks}

1. The cycle of $1 \times 1$ simulation games between the experimental and the comparative group is a system of play in which each player from a given team fights with each player from the other. We used the method of diagnosing sportsmen's actions in simulation games (Paluszek, Panfil, 1995). Thirteen players from each team participated in the games. Altogether, 169 games were played (each player played 12 games) during 6 training units. The $1 \times 1$ simulation game took place on a field with dimensions of $15 \times 20$ meters with goal posts of $1 \times 0,7$ meters. The duration of the game was $120 \mathrm{~s}$. The aim of the game was to achieve a maximal number of points by putting the ball to a goal post of the opponent and preventing the opponent from scoring the goal. The point was regarded as valid when a ball passed the light of goal with its whole circumference or when it touched a goalpost or a crossbar. After each point loss, the game started from the central area. During the game, the defending player was able to fight for a ball on the whole field of game, but he could only move back to the central area. He could move into his own goalpost only during a fight for the ball, in direct contact with the opponent. Moving the ball after the line limiting the field of game was equal with its loss. The opponent introduced the ball to the game in the place from which it left the field.

In this method, the evaluation as a whole for each player included:

- indicator of efficiency in the attack $W a=z$ where $z$ - points achieved in all the $1 \times 1$ games,

- indicator of efficiency in defense Wo $=\mathrm{s}$ where $\mathrm{s}$ - points lost in all the $1 \times 1$ games,

- indicator of complex efficiency $W k=z-s$, complex efficiency understood as the difference in the points achieved and lost in all the $1 \times 1$ games.

All the games were conducted on the soccer field of UKS "Cisowa" in Gdynia.

2. Test of general physical fitness INKF (formulated by J. Pachla and T. Ulatowski) (Talaga, 1997b). The test is composed of the following elements:

- pull-ups on a bar - attempt of an evaluation of arm muscle strength,

- bending and strengthening of arms in support on rail - attempt of an evaluation of arm muscle strength,

- reaching jump - attempt of an valuation of vault,

- run on a 60-meters distance - attempt of speed evaluation,

- run on a 300-meters distance - attempt of endurance evaluation,

- run "zigzag on an envelope" - attempt of agility evaluation. 
We have interpreted the obtained results on the basis of a point chart in T scale comparing the proper values in points. All the tests of physical fitness were conducted in a gymnasium and on the sport field of Akademia Morska in Gdynia.

To determine changes in the level of the tested parameters, we used a classic experimental plan (Table 1) (Ryguła, 2003).

Table 1. Scheme of classic experimental plan

\begin{tabular}{lccccc}
\hline \multicolumn{1}{c}{ Groups } & Selection & Initial measurement & Experimental factor & Final measurement & Difference \\
\hline Experimental & $\mathrm{R}$ & $\mathrm{P}_{1}$ & $\mathrm{X}$ & $\mathrm{P}_{2}$ & $\mathrm{~d}_{\mathrm{e}}=\mathrm{P}_{2}-\mathrm{P}_{1}$ \\
Comparative & $\mathrm{R}$ & $\mathrm{P}_{3}$ & - & $\mathrm{P}_{4}$ & $\mathrm{~d}_{\mathrm{c}}=\mathrm{P}_{4}-\mathrm{P}_{3}$ \\
\hline
\end{tabular}

$X$-independent variable (experimental factor).

$P_{1}, P_{2}, P_{3}, P_{4}$ - measurements of dependent variable.

$\mathrm{R}$ - selection to a group (randomization).

$D_{e}$ - difference between the final and the initial measurement in the experimental group.

$D_{c}$ - difference between the final and the initial measurement in the comparative group (control)

The results obtained in the tests of power, agility, speed, endurance were evaluated based on a point chart in scale $T$ with the respective values in points.

The measurement data were statistically studied at the beginning, evaluating the compatibility of the obtained results with normal distribution, applying the Shapiro-Wilk's test. To compare the level of changes of the dependent variable in the experimental and the comparative group during the experiment's duration, we conducted the test of comparing the relative differences for all the tested variables between the results of the fourth test (final) and the first (initial). In the case of rejection of the thesis about normal distribution, to determine the significance of differences in the level of the tested features, we used the $U$ Mann-Whitney test. In the case of the thesis about normal distribution acceptance, we used the test of the significance of the differences between two averages for no connected variables, hence, the t-Student test. To choose the proper version of the test, we checked the variance equality of the obtained results with the help of the $F$ test. In case of rejection of thesis about distribution's variance equality of features we applied Cochran-Cox test.

\section{Results}

\section{Efficiency of actions in $1 \times 1$ simulation games in the experimental and the comparative group during two-year resegrch period}

\section{Efficiency of defensive actions in $1 \times 1$ simulation games}

Analyzing the results of $1 \times 1$ simulation games, we evaluated the points scored and lost by a chosen player in all 12 played matches in frames of one test, which is the $1 \times 1$ tournament between the players from the experimental and the comparative group.

When evaluating the efficiency of the players' defensive actions, we set up the indicator of efficiency of game in attack $\mathrm{Wa}=\mathrm{z}$, where $\mathrm{z}$ - indicates all the points scored by a chosen player during one tournament of a simulation game (Paluszek, Panfil, 1995).

On the first term of tests, for the experimental group, the average indicator of efficiency was 24.31 points, whereas for the comparative group, it was 30.69 points. The difference in the averages was 6.59 points and it was 
not statistically significant $(p \leq 0.05)$. On the second term, the average indicator decrease in both groups (the players played less effectively in attack, scoring fewer points). In the following tests, the players from the comparative group maintain the frequency of effective offensive actions at a similar level; however, the players from the experimental group regularly improved the discussed element, achieving higher and higher values of the indicator during the third and the fourth test. In the last test, the average indicator of play in attack in the experimental group reached the value of 29.26 points; however, in the comparative group, it was 25.15 . In this case, the difference in the averages was 4.08 , which also was not statistically significant $(p \leq 0.05)$. Between the first and the fourth test, the value of the game's indicator in attack in the experimental group increased on average by 4.92 points, whereas for the comparative group, it decreased by 5.53 . The comparison of the relative differences between the average results in the fourth and the first test in both groups indicates statistically significant $(p \leq 0.02)$ differences for the benefit of the experimental group. It can be stated that during the two-year research period, the players from the experimental group streamlined their offensive actions in a $1 \times 1$ simulation game in relation to the players from the comparative group (Table 2).

\section{Ineffective defensive actions in $1 \times 1$ simulation games}

The efficiency of defensive actions in a one against one game was determined by setting the indicator of the game's efficiency in defense $W_{0}=s$, where $s$ - is the number of all points lost by a chosen player during $121 \times 1$ games during the defined test (Paluszek, Panfil, 1995). The indicator of the game's efficiency in defense for one team is the opposite of the efficiency indicator of the game in attack for the second team, as each point scored by a player on one team means a point lost by the rival.

In the first test, the players gained in the discussed element average results of 30.96 points in the experimental group and 24.31 in the comparative group. Hence, the difference in the average results was 6.38 and proved not to be statistically significant $(p \leq 0.05)$. During the fourth test, the indicator of the game in defense was as follows: 25.15 in the experimental group and 29.23 in the comparative group. This time, the differences in the averages between both groups were also statistically insignificant ( $p \leq 0.05$ ), and reached the value of 4.08 . During the twoyear period, the value of the tested elements decreased in the experimental group by 5.53 points, whereas in the comparative group, it increased by 4.92 points.

A comparison of the relative differences between the average results of the tested groups in the first and the fourth test indicated a statistical significance ( $p \leq 0.02$ ). Hence, we stated an improvement of defensive actions in the experimental group in comparison with the comparative group during the two-year period of research (Table 2).

\section{Complex efficiency of actions in $1 \times 1$ simulation games}

The efficiency of the players' actions in simulation game one against one was determined by finding the indicator of complex efficiency Wk $=z-s$, so the difference between the points scored and lost during all the $1 \times 1$ games that happened during chosen test (Paluszek, Panfil, 1995).

In the first cycle of tests, the players from the experimental group reached the average level of complex efficiency -6.38 points, whereas for the comparative group, the above-mentioned indicator was on the level of 6.38 . The difference of the averages in both groups was 12.8 points and was not statistically significant $(p \leq 0.05)$. In each following test, the average indicator in the experimental group increased, whereas for the comparative group, it decreased. In the fourth test, finishing the experiment, it amounted in the experimental group to 4.08 , on average 
and in the comparison group -4.08. This time, the average difference in the averages, which was on the level of 8.16 points, showed also not to be statistically significant $(p \leq 0.05)$. During two-year period, it was evident that there was a very definite increase of fitness among players from the experimental group in this element; the difference between the fourth test was 10.46 points. The average indicator decrease in the comparative group was of the same value. The comparison of the differences between average results of complex efficiency indicator in the fourth and the first test presented the existence of statistically significant $(p \leq 0.02)$ differences between the tested groups.

Considering the changes in the level of efficiency indicator of play in defense, in attack and the indicator of complex efficiency, it can be stated that during the observed two-year period, we noted a distinct improvement of the actions of the experimental group in relation to the comparative group in simulation game one against one (Table 2). Therefore, we stated that, during the experiment, the players of the experimental group improved their actions in relation to players from the comparative group in simulation game one against one.

Table 2. Results of measurements of number of technique-tactic actions during simulation games one against one

\begin{tabular}{|c|c|c|c|c|c|c|c|c|c|c|c|}
\hline \multirow{2}{*}{ Tested indicator } & \multirow{2}{*}{$\begin{array}{c}\text { Test } \\
\text { number }\end{array}$} & \multicolumn{4}{|c|}{ Experimental group } & \multicolumn{4}{|c|}{ Comparative group } & \multirow{2}{*}{$X e-X p$} & \multirow{2}{*}{ U Test } \\
\hline & & $\mathrm{Xe}$ & SD & Min & Max & $X p$ & SD & Min & Max & & \\
\hline \multirow{5}{*}{$\begin{array}{l}\text { Indicator of game's } \\
\text { efficiency in attack }\end{array}$} & I & 24.10 & 8.60 & 13 & 36 & 30.69 & 9.73 & 18 & 52 & -6.59 & 84.0 \\
\hline & $\|$ & 19.31 & 8.02 & 7 & 31 & 24.62 & 9.79 & 12 & 45 & -5.31 & \\
\hline & III & 26.92 & 7.55 & 15 & 39 & 26.23 & 10.99 & 9 & 50 & 0.69 & \\
\hline & IV & 29.23 & 9.06 & 10 & 41 & 25.15 & 9.37 & 12 & 45 & 4.08 & 110.5 \\
\hline & IV -I & 5.13 & 0.46 & -3 & 5 & -5.54 & -0.36 & -6 & -7 & & $138.5^{\star}$ \\
\hline \multirow{5}{*}{$\begin{array}{l}\text { Indicator of game's } \\
\text { efficiency in defense }\end{array}$} & I & 30.69 & 10.64 & 12 & 52 & 24.31 & 8.32 & 13 & 39 & 6.38 & 91.0 \\
\hline & $\|$ & 24.62 & 8.35 & 14 & 37 & 19.31 & 5.82 & 8 & 27 & 5.31 & \\
\hline & III & 26.23 & 9.96 & 13 & 46 & 26.92 & 7.25 & 14 & 38 & -0.69 & \\
\hline & IV & 25.15 & 10.03 & 13 & 45 & 29.23 & 6.65 & 19 & 42 & -4.08 & 59.5 \\
\hline & IV -I & -5.54 & -0.61 & 1 & -7 & 4.92 & -1.67 & 6 & 3 & & $27.0^{*}$ \\
\hline \multirow{5}{*}{$\begin{array}{l}\text { Indicator of complex } \\
\text { efficiency }\end{array}$} & 1 & -6.38 & 15.81 & -39 & 22 & 6.38 & 16.29 & -21 & 39 & -12.80 & 49.5 \\
\hline & $\|$ & -5.31 & 13.17 & 30 & 15 & 5.31 & 15.02 & -15 & 37 & -10.60 & \\
\hline & III & 0.69 & 16.71 & -31 & 24 & -0.69 & 16.90 & -24 & 32 & 1.38 & \\
\hline & IV & 4.08 & 17.32 & -35 & 27 & -4.08 & 14.60 & -30 & 23 & 8.16 & 115.0 \\
\hline & IV -I & 10.46 & 1.51 & 4 & 5 & -10.5 & -1.69 & -9 & -16 & & $151.0^{*}$ \\
\hline
\end{tabular}

$\mathrm{Xe}$ - arithmetic mean in the experimental group.

$\mathrm{Xp}$ - arithmetic mean in the comparative group

SD - standard deviation.

Min - minimal value.

Max - maximal value.

$\mathrm{Xe}-\mathrm{Xp}$ - the difference between average value of the experimental and the comparative group

Test- $U$ - value of $U$ Mann-Whitney test between the results of the experimental and the comparative group.

IV - I - relative difference between the fourth and the first test.

* The difference of averages statistically significant $(p \leq 0.02)$.

\section{Level of motor skills in the experimental and the comparative group in two-year research period on the stage of elementapy teaching}

The analysis of the results of the conducted test of general physical fitness INKF included in Table 3 indicates a lack of differences in the level of particular motor skills between both research groups during the experiment. In each of the four conducted tests, the average results of particular tests of motor skills between groups did not 
differ between each other in a statistically significant way ( $p \leq 0.05)$. In case of each test, which determines chosen motor skill, we noticed in the following an increase of its level in both groups. The direction and pace of changes in both groups were also similar; thus, comparative differences between average results of particular tests in the fourth and the first test in none of the cases did not show to be statistically significant. Thus, we noticed that during the two-year research period, in both groups, the general physical fitness of players was on a comparative level.

Table 3. Level of motor skills in the research groups

\begin{tabular}{|c|c|c|c|c|c|c|c|c|c|c|c|}
\hline \multirow{2}{*}{ Motor skill } & \multirow{2}{*}{ Test number } & \multicolumn{4}{|c|}{ Experimental group } & \multicolumn{4}{|c|}{ Comparative group } & \multirow{2}{*}{$X e-X p$} & \multirow{2}{*}{ T test } \\
\hline & & $\mathrm{Xe}$ & SD & Min & Max & $X p$ & SD & Min & Max & & \\
\hline \multirow{5}{*}{ Strength } & I & 27.69 & 2.75 & 26 & 35 & 27.46 & 1.76 & 26 & 32 & 0.23 & 0.36 \\
\hline & II & 27.69 & 2.56 & 26 & 34 & 27.38 & 1.55 & 26 & 31 & 0.31 & \\
\hline & III & 28.31 & 3.30 & 26 & 31 & 27.54 & 1.61 & 26 & 31 & 0.77 & \\
\hline & IV & 30.38 & 7.61 & 26 & 55 & 28.92 & 1.80 & 26 & 30 & 1.46 & $0.67^{*}$ \\
\hline & IV -I & 2.69 & 4.86 & 0 & 20 & 1.46 & 0.04 & 0 & -2 & & $0.56^{*}$ \\
\hline \multirow{5}{*}{ Power } & I & 12.69 & 8.10 & 1 & 26 & 9.92 & 3.06 & 7 & 15 & 2.77 & $1.15^{*}$ \\
\hline & II & 14.69 & 8.01 & 1 & 27 & 12.08 & 4.69 & 5 & 19 & 2.61 & \\
\hline & III & 16.85 & 7.25 & 2 & 27 & 14.38 & 5.91 & 7 & 25 & 2.47 & \\
\hline & IV & 17.38 & 8.71 & 1 & 26 & 16.23 & 7.82 & 5 & 26 & 1.15 & 0.35 \\
\hline & IV -I & 4.69 & 0.61 & 0 & 0 & 6.31 & 4.76 & -2 & 11 & & 0.90 \\
\hline \multirow{5}{*}{ Agility } & I & 43.00 & 10.12 & 13 & 55 & 40.38 & 6.53 & 28 & 50 & 2.62 & $1.15^{*}$ \\
\hline & II & 46.23 & 7.96 & 25 & 55 & 42.23 & 5.31 & 30 & 49 & 4.00 & \\
\hline & III & 48.00 & 6.00 & 38 & 57 & 44.77 & 4.53 & 35 & 50 & 3.23 & \\
\hline & IV & 49.00 & 7.06 & 37 & 56 & 47.00 & 5.18 & 37 & 55 & 2.00 & 0.82 \\
\hline & IV -I & 6.00 & -3.06 & 24 & 1 & 6.62 & -1.35 & 9 & 5 & & 0.29 \\
\hline \multirow{5}{*}{ Speed } & 1 & 42.31 & 12.65 & 22 & 60 & 40.15 & 10.68 & 25 & 53 & 2.16 & 0.66 \\
\hline & II & 46.92 & 11.69 & 25 & 60 & 41.15 & 10.06 & 16 & 55 & 5.77 & \\
\hline & III & 50.92 & $1 / .81$ & 33 & 66 & 45.54 & 12.48 & 27 & 62 & 5.38 & \\
\hline & IV & 52.85 & 12.57 & 31 & 69 & 48.77 & 14.13 & 31 & 69 & 4.08 & 0.78 \\
\hline & IV - I & 10.54 & -0.08 & 9 & 9 & 8.62 & 3.45 & 6 & 16 & & 0.78 \\
\hline \multirow{5}{*}{ Endurance } & 1 & 12.62 & 10.66 & 0 & 30 & 15.08 & 6.56 & 0 & 22 & -2.46 & 1.00 \\
\hline & ॥ & 16.54 & 12.89 & 0 & 38 & 18.86 & 10.20 & 0 & 34 & -2.32 & \\
\hline & III & 18.46 & 14.64 & 0 & 46 & 22.00 & 12.98 & 0 & 42 & -3.54 & \\
\hline & IV & 21.31 & 16.51 & 2 & 46 & 27.15 & 13.86 & 2 & 46 & -5.84 & 0.98 \\
\hline & IV -I & 8.69 & 5.85 & 2 & 16 & 12.07 & 7.30 & 2 & 24 & & 1.02 \\
\hline
\end{tabular}

$\mathrm{T}$ test $-\mathrm{t}$-Student test between average values of the experimental andd the comparative group.

${ }^{*}$ Results of Cochran-Cox test.

\section{Discussion}

Taking into consideration the collected research results, we unequivocally stated the influence of the two-year training applied in the experimental group, based on small and supporting games, on improvement of actions in $1 \times 1$ simulation games.

Testing the relations between the effectiveness in simulation games one against one and predispositions conditioning cooperation in small and qualified games, was the area of interest of Szwarc (Szwarc, 2005a, 2005b, 2005c, 2007). The author demonstrated that young players acting more effectively in simulation game $1 \times 1$ have 
also high predispositions to cooperate in games with the participation of a higher number of players and in proper game.

An essential connection between the effectiveness of a $1 \times 1$ game in a simulation game and the proper game was also noted by Paluszek and Becella (2005b). In another publication, these authors also stated that $1 \times 1$ simulation games are very similar to the proper game when it comes to their criteria and that they allow to objectively determine the abilities of individual action in games and thus classify particular players on the background of the tested group.

In turn, Witkowski and Duda (2005), researching "small $1 \times 1$ game tests", stated that the efficiency indicator of a $1 \times 1$ game is characterized by a high level of information allowing to evaluate the perspectives of soccer players.

Taking into consideration the results of the conducted INKF general fitness test, we tried to answer the question on how will the schooling based on small and supporting games influence the changes in the level of motor skills in the experimental group in comparison with the comparative group.

The analysis of the initial level of the discussed skills in both groups allow to make a statement that in each case players from both teams represented comparable level motor skills throughout the whole period of the experiment's duration. The observed slight differences were always statistically insignificant $(p \leq 0.05)$. It means that the differences in the level of some soccer player skills between groups observed during the experiment were not conditioned by the differences in the level of motor skills.

The relations between the level of motor skills and the effectiveness in a one against one game was tested, among others, by Paluszek (2000), who stated that a higher level of conditional predispositions is connected with higher effectiveness in a $1 \times 1$ simulation game. Among the conditional predispositions, endurance and speed predispositions especially have a large influence on the effectiveness of the player's behavior in a one against one game, whereas strength predispositions have a small influence.

According to other researches, the level of "explosive" strength and the level of "functional" strength have a significant influence on the effectiveness of play one against one (Żak, Pleszka, Klocek, 2005).

The above-mentioned issue was discussed also by Szwarc (2007), who stated that the high level of most of the motor predisposition (condition and coordination) positively influence the efficient behavior of player in game one against one. According to the author, strength-speed predispositions have a particularly essential meaning for efficient actions.

The analysis of the results allows to conclude that the differences, which occurred between the tested groups in the level of some soccer player's skills during two-year experiment, were not the effect of the differences in the level of motor skills.

\section{Conclusions}

The applied training based on small and supporting games positively influences the improvement of individual's actions in $1 \times 1$ simulation games, both in attacking and in defense.

Throughout the whole period of the experiment's duration, the players from both teams represented comparative levels of motor skills (strength, power, agility, speed and endurance), hence the differences that occurred between the tested groups in soccer player skills are not caused by differences in the level of general physical fitness of the tested individuals. 
Soccer training based on small and supporting games can be an effective method for the improvement of the training's effectiveness in the range of action efficiency in the situation of a $1 \times 1$ game during a proper game, which is essential for a modern game, both in an attack and defense.

Soccer training based on small and supporting games can also be a method of increasing the effectiveness of football training in the range of an improvement of individual actions accomplished in difficult situations because they are a necessary condition of effective actions in modern soccer games.

\section{References}

Bauer, G. (2001). Lehrbuch Fussball: Erfolgreiches Training von Technik, Taktik und Kondition. BLV Verlagsgesellschaft mbH.

Behnke, D.K., Sass, H. (1990). Ziele Aufgaben und Methoden der Fussballausbildung im Schulsport. Korpererziehung, 8-9, 350-353.

Bergier, J. (1990). Piłka nożna dzieci i młodzieży. Warszawa: AWF.

Bergier, J. (1998). W poszukiwaniu wyznaczników skuteczności gry w piłkę nożną. Wychowanie Fizyczne i Sport, 2, 81-91.

Cicirko, L., Syryjczyk, J. (2000). Zarys teorii i praktyki piłki nożnej. Biała Podlaska: Calamus.

Clemente, F.M., Couceiro, M.S., Martins, F.M.L., Dias, G., Mendes, R. (2013). Interpersonal Dynamics: 1 v1 Sub-Phase at Sub-18 Football Players. Journal of Human Kinetics, 36, 179-189.

Dorna, M., Robakiewicz, R., Dorożała, R. (2015). Rola gier zadaniowych w szkoleniu. Trener, 1, 8-11.

Duda, H. (2004). EURO' 2004 - analiza działań ofensywnych najlepszych zespołów. Sport Wyczynowy, 11-12, 9-15.

Duda, H. (2006). Jak Europa gra w piłkę nożną? Analiza sytuacji bramkowych w ME - Portugalia 2004. Sport Wyczynowy, 5-6, 13-22.

Fenner, J.S., Iga, J., Unnithan, V. (2016). The evaluation of small-sided games as a talent identification tool in highly trained prepubertal soccer players. J Sports Sci, 34 (20), 1983-1990.

Gołaszewski, J. (2003). Piłka nożna. Poznań: AWF.

Hamsun, G., Daniel, J. (2000). Fussball Jugentraining. Hamburg: Rororo Verlag.

Harwey, G., Dungworth, R. (1999). Szkoła piłki nożnej. Warszawa: Coronei.

Hill-Haas, S., Coutts, A., Rowsell, G., Dawson, B. (2008). Variability of acute physiological responses and performance profiles of youth soccer players in small-sided games. J Sci Med Sport, 11 (5), 487-490.

Hill-Haas, S., Coutts, A., Dawson, B., Rowsell, G. (2010). Time-motion characteristics and physiological responses of small-sided games in elite youth players: The influence of player number and rule changes. J Strenght Cond Res, 24 (8), 2149-2156.

Hill-Haas, S., Dawson, B., Coutts, A., Rowsell, G. (2009). Physiological responses and time-motion characteristics of various smallsided soccer games in youth players. J Sport Sci, 27 (1), 1-8.

Kapera, R. (1999). Piłka nożna. Warszawa: Estrella.

Kapera, R., Śledziewski, D. (1997). Piłka nożna. Unifikacja procesu szkolenia dzieci młodzieży. Warszawa: PZPN.

Kollath, E. (1998). Piłka Nożna. Technika i Taktyka. Wrocław: Oficyna Wydawnicza Marshal.

Mallo, J., Navarro, E. (2008). Physical load imposed on soccer players during small-sided training games. J Sport Med Phys Fit, 48 (2), $166-171$.

Martone, D., Giacombbe, M., Capobianco, A., Imperlini, E., Mancini, A., Campasso, M., Buono P., Orru, S. (2016). Exercise intensity and technical demands of small-sided soccer games for under-12 and under-14 players: effect of area per player. J Strength Cond Res, 18, 1615-1623.

Mayer, R. (1996). Fussball trainieren. Reinbeck: Rowohlt Taschenbuch Verlag Gmb.

Naglak, Z. (2005). Nauczanie i uczenie się wielopodmiotowej gry z piłką. Kształcenie gracza na wstępnym etapie. Wrocław: AWF.

Naglak, Z. (1996). Zespołowa gra sportowa. Studium. Wyd. II. Wrocław: AWF.

Paluszek, K. (2000). Związek pomiędzy skutecznościąw grze „jeden przeciwko jednemu” azdolnościami kondycyjnymii koordynacyjnymi. In: Bergier, J. (ed.), Sport dzieci i młodzieży na przełomie wieków (pp. 129-135). Biała Podlaska: IWFiS.

Paluszek, K. (2003). Nowoczesne nauczanie gry w piłkę nożną. Wrocław: BK Wydawnictwo i Księgarnie.

Paluszek, K., Becella, Ł. (2005a). Gry symulacyjne 1 × 1 jako czynnik doboru i selekcji np. piłki nożnej. In: Stuła, A. (ed.), Wybrane zagadnienia treningu sportowego piłkarzy nożnych (pp. 183-192). Gorzów Wielkopolski: ZWKF. 
Paluszek, K., Becella, Ł. (2005b). Skuteczność gry 1 × 1 w warunkach symulacyjnych i w grze właściwej. In: A. Stuła (ed.), Wybrane zagadnienia treningu sportowego piłkarzy nożnych (pp. 29-36). Gorzów Wielkopolski: ZWKF.

Paluszek, K., Nosal, J. (1997). Gra 1 × 1 w nauczaniu i doskonaleniu działań występujących podczas gry w piłkę nożną. In: J. Bergier (ed.), Piłka nożna - teoria i praktyka: Konferencja naukowo-metodyczna (pp. 89-107). Biała Podlaska: IWFiS.

Paluszek, K., Panfil, R. (1995). Diagnozowanie działań sportowców w grach symulacyjnych. In: Z. Naglak, R. Panfil (eds.), Zespołowe gry sportowe w wychowaniu fizycznym i sporcie (pp. 111-119). Wrocław: AWF.

Panfil, R., Żmuda, W. (1996). Nauczanie gry w piłkę nożną. Wrocław: Sportex.

Patz, D. (2000). Moje hobby piłka nożna. Poradnik dla dzieci. Warszawa: Delta W-Z.

Przybylski, W. (1998). Piłka nożna. Cz. Il. Trening. Gdańsk: AWF.

Przybylski, W., Szwarc, A. (1996). Piłka nożna. Cz. I. Technika i taktyka. Gdańsk: AWF.

Ryguła, I. (2003). Proces badawczy w naukach o sporcie. Katowice: AWF.

Stępiński, M. (2005). Pojęcie pressingu we współczesnej piłce nożnej. Trener, 2, 24-29.

Stępiński, M. (2006). Taktyka na MŚ w Niemczech. Trener, 5, 1-5.

Stępiński, M., Dorna, M. (2011). Gra 1 × 1 w piłce nożnej. Wrocław: MWW Mirosław Matoga.

Stuła, A. (1998). Skuteczność wybranych elementów gry najlepszych zespołów piłkarskich Mistrzostw Europy - Anglia '96. Sport Wyczynowy, 5-6, 20-25.

Stuła, A. (2001). Współczesna piłka nożna. Teoria i praktyka. Gorzów Wielkopolski: IWF.

Szwarc, A. (2005a). Gra jeden przeciwko jednemu - próba opisu i klasyfikacji zjawiska na przykładzie gry w piłkę nożną. In: A. Stuła (ed.), Wybrane zagadnienia treningu sportowego piłkarzy nożnych (pp. 177-182). Gorzów Wielkopolski: ZWKF.

Szwarc, A. (2012). Identyfikacja sprawności działania w grze w piłkę można w sytuacjach jeden przeciwko jednemu. In: R. Panfil, H. Zdebska (eds.), W kręgu zespołowych gier sportowych: księga jubileuszowa z okazji 80-lecia urodzin Profesora Zbigniewa Naglaka (pp. 32-39). Wrocław: AWF.

Szwarc, A. (2005b). Niezawodność we współdziałaniu a indywidualna sprawność działania gracza - badanie zależności na przykładzie gry w piłkę nożną. In: A. Stuła (ed.), Wybrane zagadnienia treningu sportowego piłkarzy nożnych (pp. 201-206). Gorzów Wielkopolski: ZWKF.

Szwarc, A. (2004). Poszukiwania wyznaczników skutecznej gry w piłkę nożną na podstawie obserwacji gry najlepszych drużyn europejskich. Wychowanie Fizyczne i Sport, 48, 53-59.

Szwarc, A. (2007). Sprawność działania w wybranych fragmentach zespołowej gry sportowej. Na przykładzie piłki nożnej. Gdańsk: AWFiS.

Szwarc, A. (2005c). Zależność pomiędzy skutecznością działania w małych grach i grze rzeczywistej u młodocianych piłkarzy. Sport Wyczynowy, 5-6, 44-47.

Szwarc, A., Kromke, K. (2011). Zmiany sprawności działania w sytuacji gry jeden przeciwko jednemu piłkarzy nożnych najwyższego poziomu zaawansowania sportowego w zależności od upływającego czasu gry i wyniku rywalizacji. In: Rocznik naukowy (pp. 23-32). Gdańsk: AWFiS.

Szyngiera, W., Bibrzycki, K. (1994). Piłka nożna dzieci i młodzieży. Katowice: AWF.

Talaga, J. (2006). ABC młodego piłkarza. Warszawa: Zysk i S-ka.

Talaga, J. (2006a). ABC młodego piłkarza. Nauczanie techniki. Poznań: Zysk i S-ka.

Talaga, J. (1997a). Atakowanie zespołowe w piłce nożnej. Trener, 3, 13-19.

Talaga, J. (2000). Atlas ćwiczeń piłkarskich. Tom II: Taktyka. Warszawa: Ypsylon.

Talaga, J. (2006b). Mundialowe refleksje. Sport Wyczynowy, 5-6, 7-12.

Talaga, J. (1996). Technika piłki nożnej. Warszawa: RCMSKFiS.

Talaga, J. (1997b). Taktyka piłki nożnej. Warszawa: RCMSKFiS

Talaga, J. (1997c). Trening piłki nożnej. Warszawa: RCMSKFiS.

Witkowski, Z., Duda, H. (2005). Przydatność „małych gier-testów 1 × 1” w ocenie perspektywiczności piłkarzy nożnych. In: A. Stuła (ed.), Wybrane zagadnienia treningu sportowego piłkarzy nożnych (pp. 193-200). Gorzów Wielkopolski: ZWKF.

Witkowski, Z., Ljach, W. (2004). Ćwiczenia kształtujące koordynacyjne zdolności motoryczne w piłce nożnej. Warszawa: COS.

Wrzos, J. (2005). Piłkarska reprezentacja Polski na tle europejskiej i światowej elity. Sport Wyczynowy, 3-4, 28-47. 
Wrzos, J. (1998). Piłkarskie Mistrzostwa Świata '98 - skuteczność wybranych działań techniczno-taktycznych (I). Sytuacje $1 \times 1$. Sport Wyczynowy, 9-10, 28-33.

Wrzos, J. (1999). Skuteczność działań techniczno-taktycznych w sytuacjach 1×1 na najwyższym poziomie światowym w piłce nożnej. Trener, 3, 9-17.

Wrzos, J. (2000). Wzorce czynności technicznych piłkarzy światowej klasy. Sport Wyczynowy, 5-6, 17-38.

Zieliński, A. (1999). Czynniki określające przebieg i skuteczność akcji ofensywnej w grze w piłkę nożną. Sport Wyczynowy, 7-8, 39-47.

Żak, S., Pleszka, P., Klocek, T. (2005). Poziom wybranych zdolności motorycznych i cech somatycznych a efektywność indywidualnej gry młodych piłkarzy nożnych. In: S. Żak, M. Spieszny, T. Klocek (eds.), Gry zespołowe w wychowaniu fizycznym i sporcie (pp. 190-196). Kraków: AWF.

Cite this anticle aS: Lachowicz, A. (2017). Effectiveness of Training for 11-13 year-old Soccer Players on the Basis of Small and Supporting Games in the Context of Action Efficiency in the Situation of a One Against One Game. Central European Journal of Sport Sciences and Medicine, 19 (3), 19-30. DOI: 10.18276/cej.2017.3-02. 